\title{
Subject-verb Word Order in Narratives in Swedish by Immersion and Non-immersion Students
}

\author{
Eeva-Liisa Nyqvist \\ Finnish, Finno-Ugrian and Scandinavian Studies, University of Helsinki, Finland
}

\begin{abstract}
The Swedish V2 word order has been considered a notorious source of difficulty for L2 learners due to its strict rules. This study explores subject-verb word order in texts written in Swedish by 12-year-old and 15-year-old Finnish-speaking immersion students and by 16-year-old non-immersion students. Although the $\mathrm{L} 1$ of the informants lacks obligatory inversion, the analyses show that informants in all three groups have reached a high accuracy level in several aspects of word order in main clauses. However, the informants struggle with challenges that are similar to those detected in previous research: inversion is omitted in its obligatory occasions in main clauses but simultaneously overused in subordinate clauses where word order is canonical. In main clauses, the challenges focus on declarative main clauses with inversion. In subordinate clauses, on the contrary, the challenges focus on questions.
\end{abstract}

Index Terms - L2 Swedish, immersion, usage-based grammar, subject-verb word order

\section{INTRODUCTION}

Immersion is a second language (L2) teaching programme aimed towards functional bilingualism, the ability to use both the first language (L1) and the target language (TL) effectively and appropriately for different purposes (Genesee 2004). Acquisition begins at daycare and continues at school via exposure to the TL with help from teachers who speak only the TL, as well as through meaningful interaction (Baker 2011). Immersion students do not acquire a nativelike proficiency, but they do better than students in non-immersion instruction (Lyster 2007; Bergroth 2015). However, international studies (Harley 1993, 1998 on Canadian French; Ó Duibhir 2009 on Irish Gaelic) have revealed that immersion pupils struggle with grammatical accuracy. Immersion research has been multifarious in Finland (Bergroth/Björklund 2013), but syntax has previously reached minor attention (see Nyqvist 2020, 2021).

This article focuses on how Finnish-speaking immersion pupils use subject-verb word order (henceforth word order) in declarative clauses (henceforth declaratives) and questions and what kinds of difficulties they have with these constructions at the end of primary school $\left(6^{\text {th }}\right.$ grade, age 12$)$ and at the end of secondary school and immersion ${ }^{1}\left(9^{\text {th }}\right.$ grade, age 15). They are also compared to a control group of 16-year-old non-immersion students. Previous research on word order has been multifarious both in Swedish grammar and L2 Swedish. It is vital, however, to study immersion separately from non-immersion settings. Immersion is an especially intensive and long-term learning programme combining rich input, communication and focus on form, which discerns it from other methods (see also Nyqvist 2018ab; Nyqvist/Lundkvist 2020; Nyqvist 2021; Nyqvist/Lahtinen 2021).

Word order has proven to cause problems for even advanced learners of L2 Swedish, whose inaccuracies are rare but qualitatively like those made by less advanced learners (Hyltenstam 1988, 1992). This is also likely to occur with the actual informants. This study analyses learning results from three perspectives (cf. Housen/Simoens 2016). Younger and older immersion students are compared to one another and to non-immersion students (learner-and context-related perspective, respectively). An analysis of the problems encountered by the informants also identifies the most difficult aspects of word order (feature-related perspective) that explicit instruction should focus on. The learners benefit most from instruction focusing on difficult constructions (DeKeyser 2003). It is crucial to explore the difficulty of constructions by analysing language produced by L2 speakers instead of only analysing the grammatical descriptions of a language. What a linguist estimates as difficult may not be that for an L2 speaker (Hammarberg 2008); conversely, an L2 speaker might struggle with a construction a linguist would not consider problematic.

\section{THEORETICAL BACKGROUND}

\section{A. Subject-verb Word Order in Swedish}

The word order in Swedish "varies within rather strict frames" (my translation, Teleman et al. 1999b:5) as it is used to distinguish between main and subordinate clauses, declaratives and questions, and between subject and object in an actual clause. Of declarative main clauses in different genres of both written and spoken Swedish, 60-70\% follow the

\footnotetext{
${ }^{1}$ There are no immersion upper secondary schools in Finland (Bergroth 2015).
} 
canonical (straight) word order (ex. 1a) where the subject precedes the finite verb, with the proportion somewhat lower in written language (Jörgensen 1976). This word order is neutral and does not emphasise any particular sentence element (Teleman et al. 1999b).

Swedish is a V2-language, i.e. the finite verb (henceforth verb) can be preceded by only one constituent and typically occurs in second position in main clauses (Teleman et al. 1999b). Thus, if a constituent other than the subject is fronted, subject-verb inversion (henceforth inversion, ex. 1b) is obligatory:

$\begin{array}{lll}\text { 1a. Han } & \text { kommer } & \text { i morgon. } \\ \text { he } & \text { comes } & \text { tomorrow } \\ \text { "He comes tomorrow." } & \end{array}$

$\begin{array}{ll}\text { 1b. I morgon kommer } & \text { han. } \\ \text { tomorrow comes } & \text { he } \\ \text { "He comes tomorrow." } & \end{array}$

Inversion also occurs in direct questions. Yes/no questions (ex. 2a) begin with the verb followed by the subject, and inversion is the sole marker for a question, whereas the interrogative word precedes the verb in questions beginning with an interrogative word (ex. $2 \mathrm{~b}$, henceforth $v$-questions, as most Swedish interrogative words begin with the letter $v$ ). The only exception is direct questions where the interrogative word is the subject or part of it (ex. 2c), and the word order is canonical (Teleman et al. 1999b).

$\begin{array}{lll}\text { 2a. Ar } & \text { allt } & \text { ok? } \\ \text { is } & \text { everything } & \text { OK } \\ \text { "Is everything OK?" } & \\ & \\ \text { 2c. Vem } \quad \text { gjorde } & \text { det? } \\ \text { who did } & \text { it } \\ \text { "Who did it?" } & \end{array}$

The word order in subordinate clauses is canonical, i.e. the subject precedes the verb:

$\begin{array}{clll}\text { 3. Jagtror att } & \text { han } & \text { kommer } & \text { i morgon. } \\ \text { I believe that } & \text { he } & \text { comes } & \text { tomorrow }\end{array}$

"I believe that he comes tomorrow."

\section{B. Usage-based Grammar and Aspects of Difficulty}

Usage-based grammar defines both L1 and L2 acquisition as a spontaneous process of rule internalisation that occurs when the learner focuses on meaning, i.e. grammar is considered an implicit cognitive organisation of a learner's actual language experience (Bybee 2008). Children acquiring their L1 memorise concrete, linguistic units combining both form and meaning (e.g. suffixes, single words and longer utterances). The learners discover regularities and start varying them, which leads to the discovery of abstract formulae (henceforth constructions) behind the concrete utterances (Lieven/Tomasello 2008).

It is appropriate to draw parallels between L1 and L2 acquisition, as both begin early and occur via communication. The essential difference between L1 and L2 acquisition, however, is the fact that immersion pupils already have an L1. Simultaneously, it is clear that many L2 constructions cannot be learned without explicit instruction (N. Ellis/Wullf 2015), even though it is possible in the L1. Moreover, the knowledge of languages is acquired in immersion through practice; hence, it is available for unconscious use, and difficult to change afterwards if the practice leads to inaccuracies. In traditional instruction, the problem is usually the opposite: a learner might have a lot of factual information they may not be able to use in actual communication (R. Ellis 2008).

R. Ellis (2006) summarises the factors that make a construction difficult to acquire implicitly. Among these are frequency, saliency, functional value and processability relevant for word order. It is easier to learn traits occurring frequently in the input, and repetition reinforces memory representations (Goldberg/Casenhiser 2008). Moreover, sequences that occur frequently in the input can be acquired as wholes, which helps the learner analyse less frequent tokens of the same construction (Bybee 2008). In Swedish, canonical word order is more common than inversion in main clauses (Jörgensen 1976), which favours its acquisition. In classroom language, it is also possible that teachers still consciously prefer utterances with the canonical word order, which cuts down the learner's possibilities of receiving input that provides positive evidence of inversion (cf. Håkansson 1987). Subordinate clauses are also less frequent than main clauses in the input (ca 30\% in study materials and newspapers vs over $40 \%$ in texts by Swedish students in upper secondary school; Hultman/Westman 1977), which might hinder their acquisition. Still, even highfrequency elements might be challenging if they are difficult to notice in the input, i.e. they have low salience (Goldschneider/DeKeyser 2005; Bybee 2008; N. Ellis 2016;). Word order is more salient in the input than e.g. several grammatical morphemes (Jensen et al. 2020), but inversion in declaratives appears to be less salient than inversion in direct questions, as it is communicatively expendable contrary to direct questions (Lund 1997).

Moreover, challenges are to be expected if a construction has a high functional value, i.e. several functions in the 
language, making the link between form and meaning opaque (DeKeyser 2005). In word order, it might be perplexing for L2 learners to notice that declaratives can have both canonical and inverted word order and that both declaratives and questions can have inverted word order. Declarative main and subordinate clauses, then again, have approximately the same meanings, but they can have different word orders. The accurate use of different word order types also requires the ability to manage the distinction between main and subordinate clauses, but this has proved challenging (Ganuza 2008; Rahkonen/Håkansson 2008).

Finally, the processability of a construction impacts how challenging a construction is. In Swedish, Processability Theory has five processability levels, and the mastery of a higher level necessitates mastery of the lower ones. Main clauses with canonical word order (SVO) occur at level 2, inversion at level 4, and the word order typical of subordinate clauses at level 5. (Pienemann/Håkansson 1999.) Subordinate clauses are likely to be especially challenging, particularly the subordinate questions, as corresponding direct questions have basically the same meaning but different form (cf. DeKeyser 2005) ${ }^{2}$ :

$\begin{array}{lll}\text { 4a. Vad } & \text { menar } & d u ? \\ \text { What mean } & \text { you } \\ \text { "What do you mean?" } & \end{array}$

\begin{tabular}{lcc} 
4b. Jag förstår vad & \multicolumn{1}{c}{} & menar. \\
I understand what & you & mean \\
"I understand what you mean." &
\end{tabular}

If a construction is difficult to acquire implicitly, it is well founded to enhance the acquisition with explicit instruction (DeKeyser 2003). Explicit instruction is often based on grammar rules, and hence, a crucial factor determining how difficult a construction is to acquire explicitly is how opaque the rule is. Simple, comprehensible rules are the most feasible, but word order requires use of extensive metalanguage: most formulations involve such terms as subject, verb, adverbial and main and subordinate clause, which are fundamental for grammarians but sometimes problematic for L2 learners, especially for younger ones (cf. R. Ellis 2006).

Transfer from the L1 can hamper acquisition if the L2 is more complex than the L1 (Collins et al. 2009). As Finnish lacks obligatory inversion (Karlsson 2017), this is actually the case for Finnish-speaking L2 speakers of Swedish. Transfer can likewise stem from other L2s acquired by the learners (De Angelis 2007). Since the informants in this study learn English at school and live in continuous contact with it, it likely plays a role in their Swedish acquisition (Bohnacker 2006). However, English also lacks obligatory inversion in declaratives (Holmes/Hinchcliffe 1994) and, thus, cannot contribute to its acquisition in Swedish.

\section{Previous Research: Word Order in L2 Scandinavian Languages}

Children acquiring their L1 do not appear to experience difficulties with word order (Håkansson 1988, 1998; Lange/Larsson 1973), although they use inversion more than adults do (i.e. in ca $50 \%$ of their utterances; Jörgensen 1976). Certain studies claim that inversion is not especially difficult in L2 contexts if both the learner's L1 and TL follow the V2 rule (Brautaset 2004; Bohnacker 2006; Johansen 2008). There is still a multitude of evidence (both written and spoken data with informants with different L1s) showing that inversion is difficult for L2 learners whose L1 lacks obligatory inversion, such as Finns (Karlsson 2017; see Lund 1997 for L2 Danish and Saarik 2006 for L2 Norwegian). Next, the central results from previous research in Swedish, Norwegian and Danish as L2s are summarised, as these closely related Scandinavian languages follow similar rules for word order (Allan et al. 2000; Strandskogen/Strandskogen 1995).

Omitted inversion in declarative main clauses is a long-standing trait in L2 Swedish. Inversion was challenging in a cloze test by Hyltenstam's (1978) adult informants, who followed the same development irrespective of the L1 and education level: $\mathrm{SVX}^{3} \rightarrow * \mathrm{XSV} \rightarrow \mathrm{XVS}$. Type of subject (e.g. pronoun, NP) or finite verb (auxiliary or main verb) did not impact the results. Following the Processability Theory, this order was also detected in the meta-analysis by Pienemann/Håkansson (1999). Ganuza (2008), however, found that the overuse of canonical word order in obligatory occasions for inversion was very rare in the declarative main clauses by adolescent L2 learners, although it was more common in informal communication situations.

Many studies have explored whether accurate use of inversion depends on the fronted constituent. In Bolander, (1988, oral data from adult learners with three different L1s), object had the highest accuracy and subordinate clause the lowest. The most common fronted object, however, was det (e.g. Det vill jag ha, "I want IT"); i.e. use of formulaic language (Wray 2012) might explain the high accuracy. Fronted subordinate clauses were challenging for Åberg's (2020, both written narratives and grammaticality judgement tests) adult informants. Similar results have been found in studies of L2 Norwegian, which implies that fronted subordinate clauses burden one's information processing capacity (Hagen 1992). Åberg (2020) also found that her informants' accurate use of inversion in written data improved due to explicit instruction, and the positive effect could also be seen in a post-test taken after the course.

Direct questions favour the accurate use of inversion when compared to the acquisition of inversion in declaratives

\footnotetext{
${ }^{2}$ The difficulty is also explainable by the low frequency of the subordinate questions and problems distinguishing subordinate and direct questions from one another (Rahkonen/Håkansson 2008).

${ }^{3} \mathrm{~S}$ stands here for subject, $\mathrm{V}$ for (finite) verb and $\mathrm{X}$ for any sentence constituent other than subject or verb. 
(Salameh et al. 1996; Philipsson 2007; Ganuza 2008; Åberg 2020; see also Lund 1997 for L2 Danish). Direct questions are also mastered before subordinate ones (Philipson 2007; Rahkonen/Håkansson 2008; Åberg 2020).

In subordinate clauses, especially questions, the main problem is the overuse of inversion (Hyltenstam/Lindberg 1983; Viberg 1990; Ganuza 2008; Nyqvist 2020; see also Hagen 1992). Philipsson's (2007) informants with the lowest competence level (young immigrants with three different L1s), however, had higher accuracies in the word order in subordinate questions because they had not yet mastered inversion in direct questions; it was a case of a certain pseudoaccuracy. The more advanced informants had several occurrences of inversion in their subordinate clauses, as they had acquired it in the direct questions but were not yet able to distinguish between main and subordinate clauses.

To summarise, previous research with varying elicitation methods and with informants of varying ages and L1s shows that the obligatory occasions for inversion are challenging for L2 learners: omitted inversion is a typical inaccuracy for declarative main clauses, whereas overuse of inversion is typical of subordinate clauses.

\section{DATA AND METHOD}

The data consist of circa 200-word narratives (entitled My Dream Journey/Holiday) and shorter e-mail tasks eliciting questions. These are written by immersion students in the $6^{\text {th }}$ and $9^{\text {th }}$ grades (henceforth IM6 and IM9) and by a control group of non-immersion students in the $1^{\text {st }}$ grade in upper secondary school (henceforth CG). The same data have been used in previous studies on Swedish grammar acquisition by Finnish-speaking immersion and non-immersion students (see Nyqvist 2018ab; Nyqvist/Lundkvist 2020; Nyqvist/Lahtinen 2021). The informants produced, on average, 265,9 words in IM6, 280 words in IM9 and 250,4 words in CG.

All informants' L1 is Finnish, and they started learning English at the age of nine (FNBE 2014a); i.e. Swedish is the L2 and English an L3 for immersion students, whereas the control group has English as their L2 and Swedish as their L3. The informants in IM6 and IM9 have learned Swedish from the age of 4-5 years, i.e. for 8-9 years (IM6) and 1112 years (IM9), respectively. They have received instruction in both Swedish and Finnish, and the proportion of the languages has varied in different grades in such a way that immersion pupils receive $50 \%$ of all their instruction in Swedish during comprehensive school. The actual proportion of instruction in Swedish is $50 \%$ in the $6^{\text {th }}$ grade and $45 \%$ in the $9^{\text {th }}$ grade $^{4}$ (Bergroth/Björklund 2013). In the immersion, the standards set for competence in the target language are fundamentally higher than in the non-immersion. At the end of immersion, students have to reach B-level ${ }^{5}$ on the CEFR scale in order to reach a level of "good" (Bergroth 2015).

In comprehensive school, CG had received instruction in around 450 Swedish lessons (FNBE 2014a; Government Decree 422/2012), and their expected CEFR level in writing to reach a score of "good" at the end of secondary school was A.2 (FNBE 2014b). CG had taken three of the six obligatory courses ${ }^{6}$ in Swedish during the first year in upper secondary school (FNBE 2015). They had probably received more formal instruction than the immersion groups, whose SLA emphasises communication (e.g. Baker 2011). Explicit grammar instruction has also been diminished in nonimmersion settings in Finland (Jaakkola 2000), but word order is still a central part of it (FNBE 2014b, 2015).

As in previous research with the same data (Nyqvist 2018ab; Nyqvist/Lundkvist 2020; Nyqvist/Lahtinen 2021), quantitative data analysis on the group level was founded on obligatory occasions (Ellis/Barkhuizen 2005), i.e. constructions that the informants are expected to use in line with Svenska Akademiens Grammatik (Teleman et al. $1999 \mathrm{ab})$. Frequencies were computed by dividing the number of a certain clause type by the number of all clauses, and the accuracy scores were obtained by dividing the number of accurate obligatory occasions of a clause type by the total number of obligatory occasions of that same clause type. High accuracy scores are interpreted to imply early acquisition, i.e. an easy construction (Collins et al. 2009). It is probable that the informants in different grades reach different competence levels, but individual variation also needs to be taken into account: one might remain at a low level after a long learning time. Furthermore, accuracy does not necessarily signify mastery. Individuals that only master canonical word order can reach high levels of accuracy by avoiding obligatory occasions for direct questions and fronted constituents other than the subject. This has also been documented in constructions other than word order (cf. Nyqvist/Lahtinen 2021).

The statistical significance of the differences in accuracy scores between the groups was determined with the statistical software package SPSS. Pearson's $\chi^{2}$ (value of $\mathrm{p}<0.05$ ) was chosen as a statistic test as it does not require Gaussian distribution. The same tests have been used in previous studies on the same data (see Nyqvist 2018ab; Nyqvist/Lundkvist 2020; Nyqvist/Lahtinen 2021). The central research questions are:

1. What is typical of the language produced by informants in regards to the proportions of main and subordinate clauses, of declarative and interrogative clauses, and of canonical word order and inversion?

2. Are main clauses more accurately used than subordinate ones?

3. Are there accuracy differences between declaratives and questions in regards to inversion?

4. Is canonical word order in main clauses more accurately used than inversion?

5. Are there accuracy differences between declarative and interrogative clauses in subordinate clauses?

\footnotetext{
${ }^{4} 85 \%$ in the first and second grades, $60 \%$ in the third and fourth grades (Bergroth/Björklund 2013).

${ }^{5}$ In non-immersion settings, students have to reach level A2 in order to reach a level of "good" in the ninth grade (FNBE 2014b).

${ }^{6} 38$ lessons excluding homework (FNBE 2015).
} 
6. What kinds of accuracy differences are there between the informant groups?

\section{ANALYSIS}

The data consist of 10702 clauses. Of these, 3789 occur in IM6, 3801 in IM9 and 3112 in CG. As this study focuses on subject-verb word order, the clauses lacking either subjects or finite verbs have been omitted from the analyses. Main clauses dominate in all informant groups (77,8\% in IM6, 69,9\% in IM9 and 73,2\% in CG). Subordinate clauses are most frequent in IM9 $(30,1 \%)$. The proportions in IM6 (22,2\%) and CG $(26,8 \%)$ are somewhat smaller than in Hultman and Westman (1977), whereas IM9 reaches a similar proportion of subordinate clauses as study materials and newspapers, which are apparently the genres they often read.

In section A, main clauses are analysed from four points of view: Firstly, the frequencies for the different types of the main clauses are given. Secondly accuracies are compared between declaratives and direct questions. Thereafter, accuracies are compared for declarative main clauses and direct questions. Finally, accuracies for declarative main clauses with canonical word order and inversion are compared. In section B, accuracies for subordinate declaratives and subordinate questions are compared to one another and to corresponding main clauses.

\section{A. Main Clauses}

In this section, I will present the accuracy scores for main clauses in IM6, IM9 and CG. Diagram 1 illustrates the distribution between declarative main clauses and direct questions.

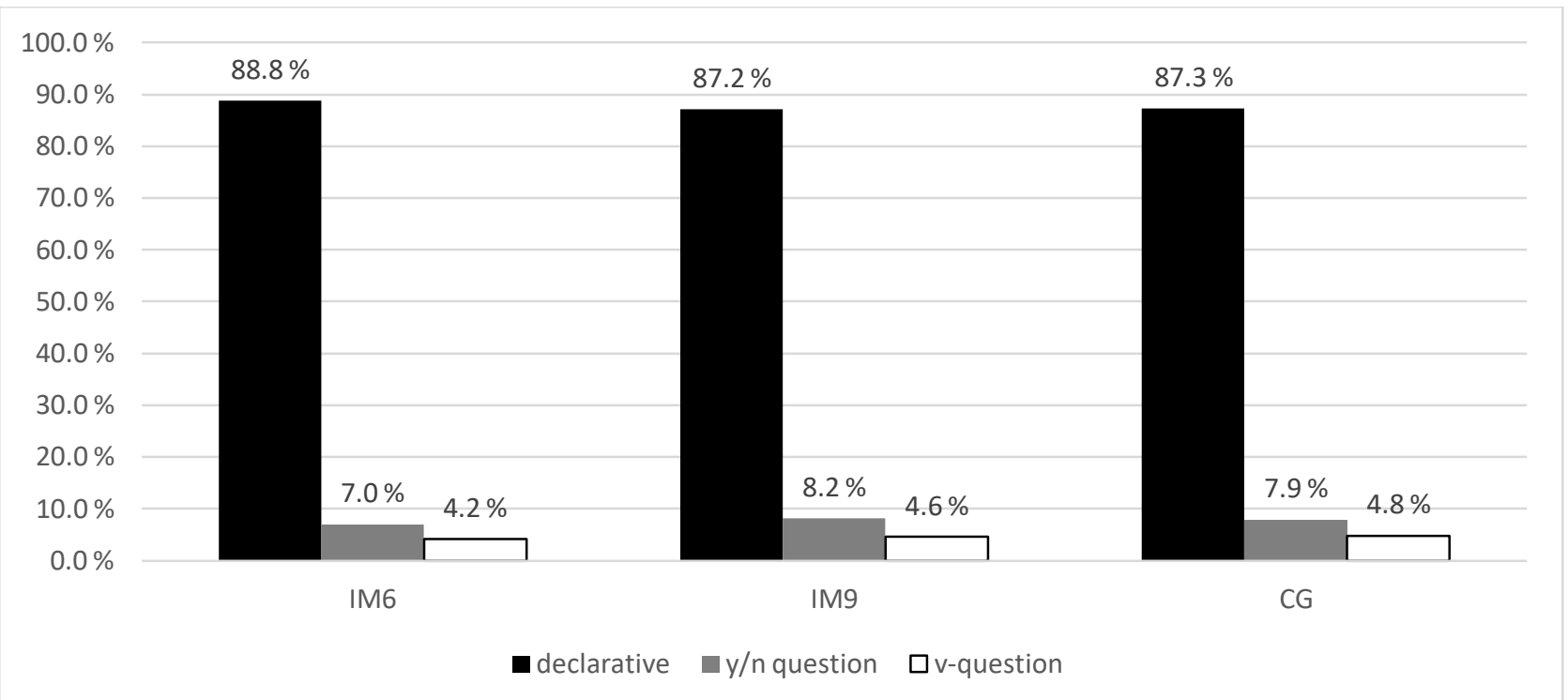

Diagram 1: Frequencies for declarative main clauses and direct questions

A majority of main clauses produced by the informants are declarative, whereas the frequency of direct questions is a little over $10 \%$ in all groups. The questions occur especially in the e-mails, which aim to elicit questions that are sporadic in the longer holiday texts. The most common questions by the informants reflect the requests typical for communication at school: e.g. kan du (“can you..."), måste/ska jag ("should I"), vilka sidor ("which pages"), vad har ni gjort ("What have you done?"). Yes/no-questions dominate in all groups.

Obligatory occasions for canonical word order dominate in declarative main clauses in all groups. In CG, as much as $78.2 \%$ of declarative main clauses have an obligatory occasion for canonical word order (65.1\% in IM6, 70.2\% in IM9). Obligatory occasions for inversion in declaratives are most frequent in IM6 (34.9\%, 29.8\% in IM9, 21.8\% in CG). Hence, CG might avoid inversion, whereas the percentages in the immersion groups are approximately similar to those in spoken L1 Swedish (Jörgensen 1976). The similarity to the spoken language in immersion groups is explainable firstly because informants are young persons who write in a rather informal style and secondly because immersion emphasises oral communication (Bergroth 2015), which might affect the writing style of the immersion students.

In contrast, more than $98 \%$ of direct questions in all groups manifest as obligatory occasions for inversion, i.e. questions where the interrogative word is the subject or part of it (see ex. 2c above) are rare (1 occurrence in IM6, 5 in both IM9 and CG). Diagram 2 illustrates overall accuracies for declarative main clauses (which do not distinguish between canonical word order and inversion) and direct questions. The two types of questions are treated as one group as they both reach high accuracy. 


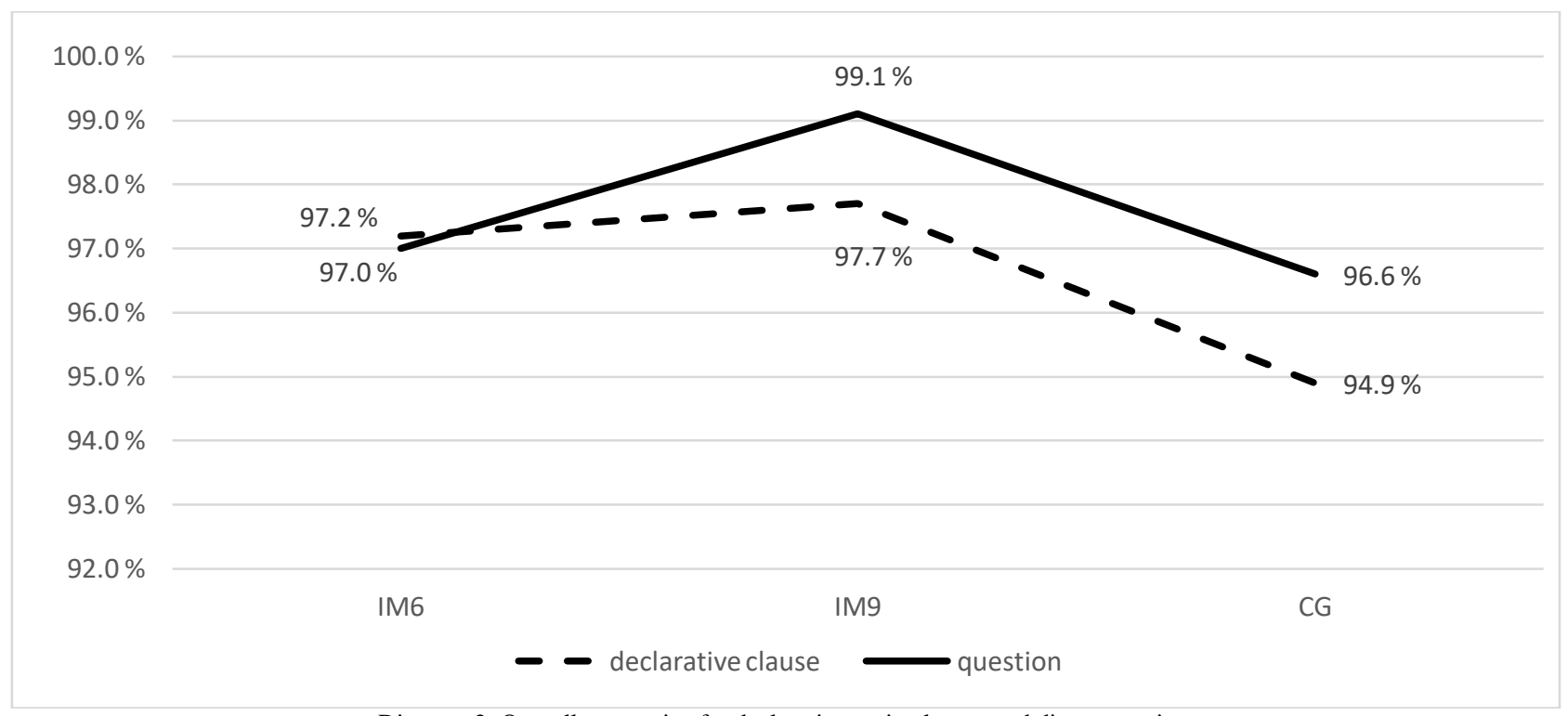

Diagram 2: Overall accuracies for declarative main clauses and direct questions

The overall accuracies for main clauses always exceed $90 \%$. Both accuracies are at the same level in IM6, whereas interrogative clauses reach higher accuracies than declaratives in IM9 and CG. However, differences between declaratives and questions are nonsignificant in all groups.

IM9 reaches higher accuracies than the other groups in both declaratives and questions. Although the differences are small, the accuracies in IM9 are significantly higher than in CG ( $p<0.001$ in declaratives; $p=0.024$ in direct questions), whereas the differences between IM6 and IM9 are nonsignificant. In declaratives, the accuracy in CG (which has probably received more explicit instruction in grammar than the immersion groups) is also significantly lower than in IM6 ( $<$ 0.001). Inaccuracies are rare in direct questions, but they typically involve the overuse of canonical word order in questions where the interrogative word is not the subject or part of it (as in Philipsson 2007; Aberg 2020):

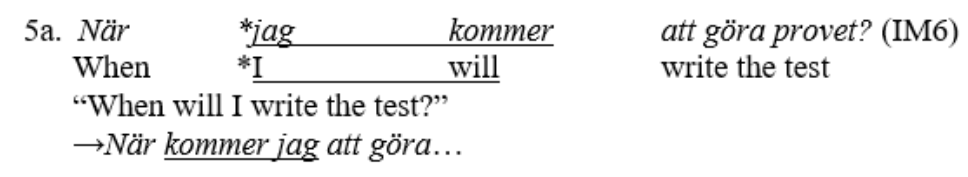

In declaratives, conversely, the typical inaccuracy concerns omitted inversion similarly to previous research (Hyltenstam 1978; Bolander 1988; Rahkonen/Håkansson 2008; Ganuza 2008). This is explainable firstly by the fact that inversion is less frequent in the input than canonical word order (Jörgensen 1976). Secondly, inversion in declaratives is a communicatively expendable construction. Thirdly, both the L1 of the informants, Finnish, and their other L2, English, lack obligatory inversion (Holmes/Hinchcliffe 1994; Karlsson 2017):

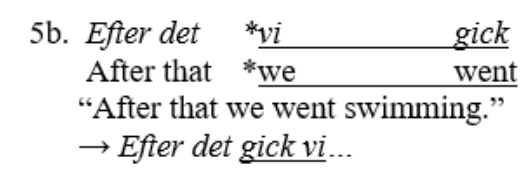
och simma. (IM9) swimming

Diagram 3 demonstrates differences in the accuracy of inversion in declarative main clauses and direct questions: 


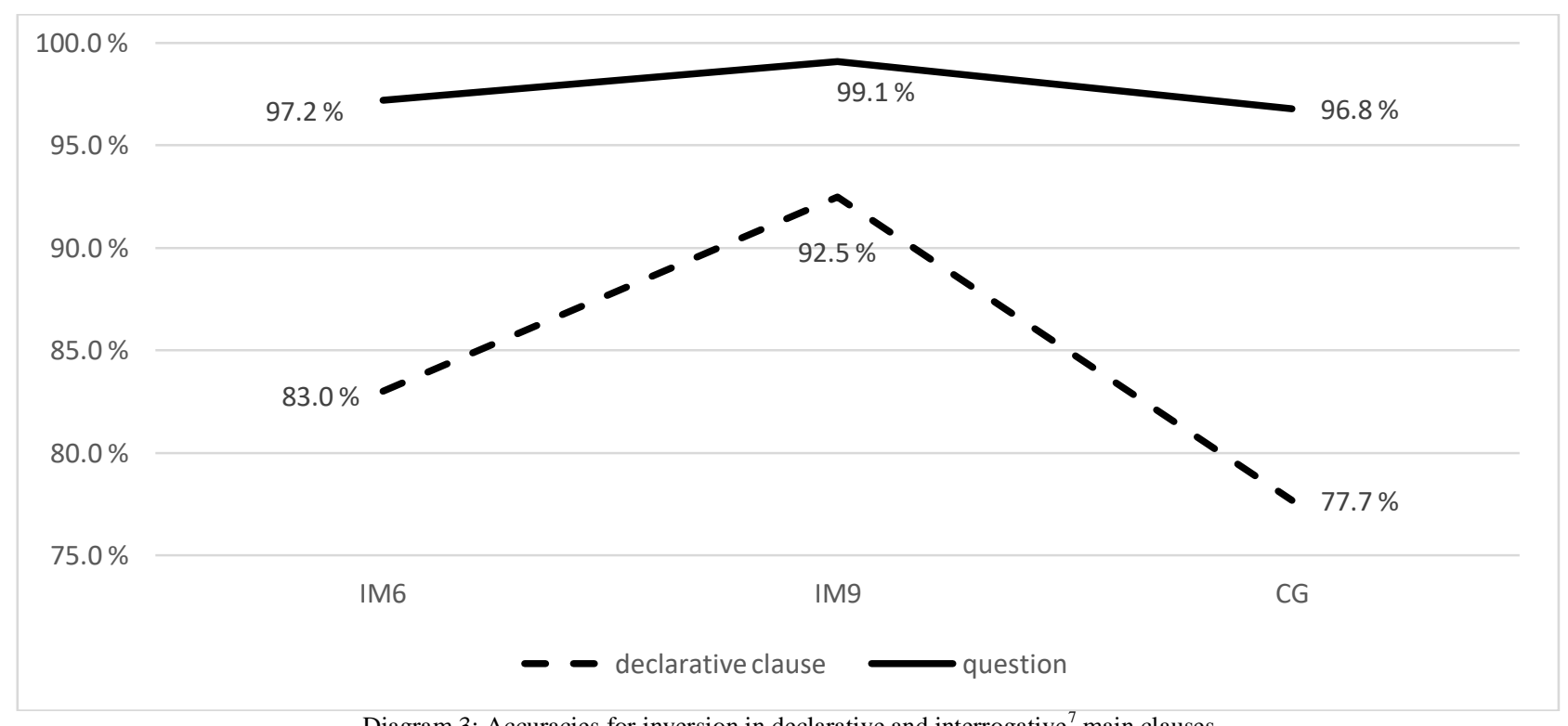

Diagram 3: Accuracies for inversion in declarative and interrogative ${ }^{7}$ main clauses

The declarative main clauses with inversion typically begin with temporal (e.g. sedan, "then"; nästa dag, "next day") and spatial (e.g. där, "there"; $i$ London, "in London") adverbs, reflecting the themes of the narratives. Direct objects beginning a main clause also occur sporadically: Opera vill jag inte höra ("Opera is something I don't want to hear").

Accuracies for inversion in direct questions are significantly higher than in declaratives ( $\mathrm{p}<0.001$ in all groups), as in previous studies (Salameh et al. 1996; Åberg 2020). This is not surprising, as inversion is most consequently used in questions where the link between form and meaning is also less opaque than in declaratives (cf DeKeyser 2005). It is likewise less common in declarative main clauses (Jörgensen 1976) and lacks communicative weight (Lund 1997). Moreover, both Finnish and English lack obligatory inversion in declaratives (Holmes/Hinchcliffe 1994; Karlsson 2017). Questions are likewise common in the classroom language and study materials, i.e. they have high frequency in the input, and they also usually have inversion in English, which may have contributed to the acquisition (cf Bohnacker 2006). IM9 reaches a significantly higher accuracy than both IM6 and CG in both clause types ( $<<0.001$ in both cases in declaratives, $\mathrm{p}=0.046$ in IM6 vs IM9 and p=0.042 in IM9 vs CG in questions), although CG has received more grammar instruction than IM6 and IM9.

Omission of inversion is common when a sentence begins with a subordinate clause, e.g. Om jag skulle få åka till USA jag skulle gå till... ("If I could go to the USA, I'd go to..."). This is especially common in CG, where up to $38 \%$ of omitted inversions occur after a subordinate clause. The percentage is significantly higher than in IM6 (14,6\%, $\mathrm{p}<0.001)$. A sentence construction beginning with a subordinate clause has proved challenging for L2 learners in previous studies (Bolander 1988; Ganuza 2008; Åberg 2020; see also Hagen 1992). In IM6, however, 70\% of omitted inversions occur in main clauses beginning with a temporal adverbial (50\% in IM9), i.e. this inaccuracy also occurs in other contexts. Diagram 4 compares inversion and canonical word order in declaratives:

\footnotetext{
${ }^{7}$ Direct questions with an interrogative word as subject (see ex. 2c) have been omitted from this diagram.
} 


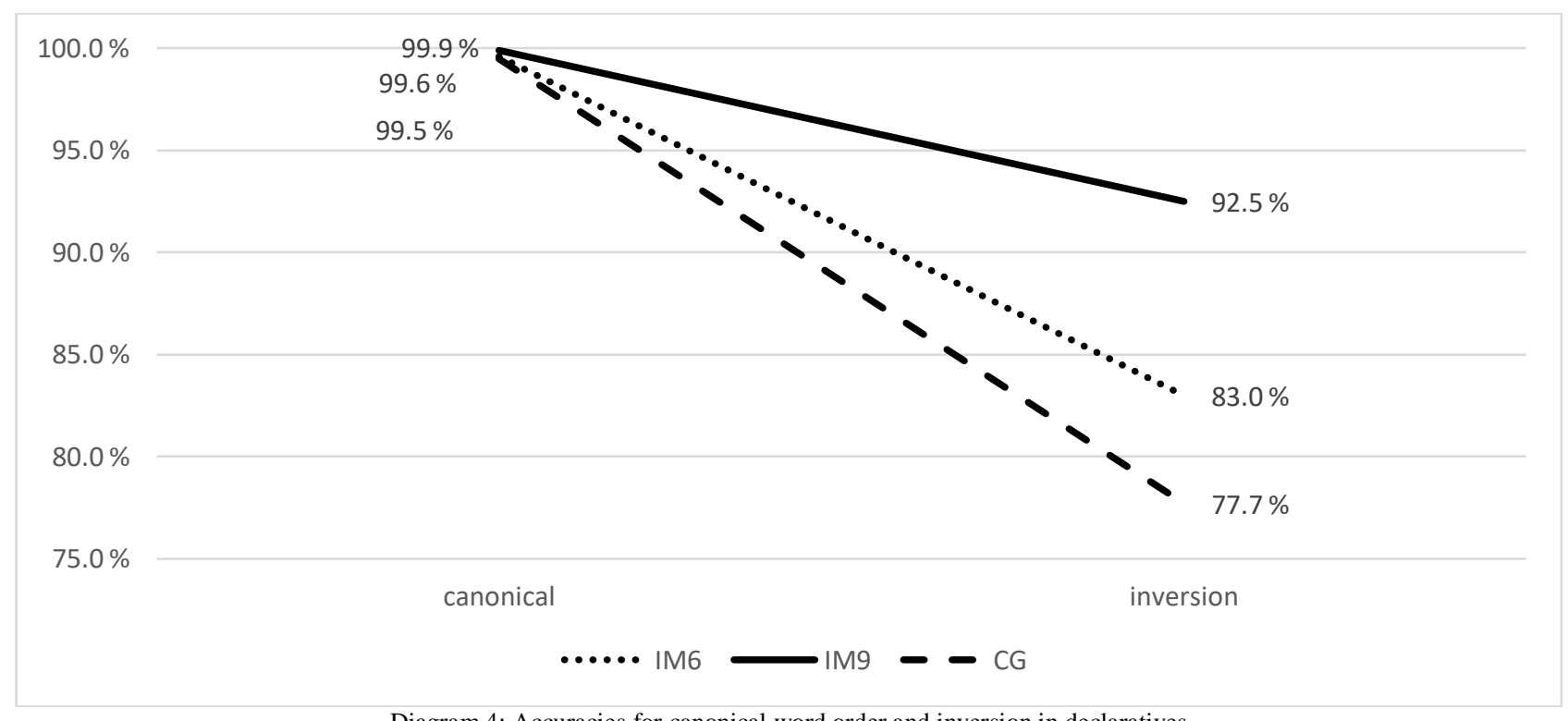

Diagram 4: Accuracies for canonical word order and inversion in declaratives

When accuracy in declarative main clauses with inversion (see above) is compared to that of main clauses with canonical word order, one can see that the latter have extremely high accuracies in all groups. Conversely, clauses with inversion reach significantly lower accuracies than clauses with canonical word order ( $<0.001$ in all groups).The differences between informant groups are nonsignificant. The high accuracies for canonical word order are not surprising, as it is high frequency in the input (Jörgensen 1976) and is acquired at an early stage (Pienemann/Håkansson 1999).

\section{B. Subordinate Clauses}

As diagram 1 shows, subordinate clauses are less frequent than main clauses. A majority of subordinate questions are declaratives $(86,8 \%$ in IM6, $86,7 \%$ in IM9 and $87,9 \%$ in CG), i.e. subordinate questions are rather low frequency in the data (109 in IM6, 151 in IM9 and 101 in CG; cf. Hyltenstam/Lindberg 1983; Viberg 1990). As Diagram 5 shows, the inaccuracies are scarce in subordinate declaratives:

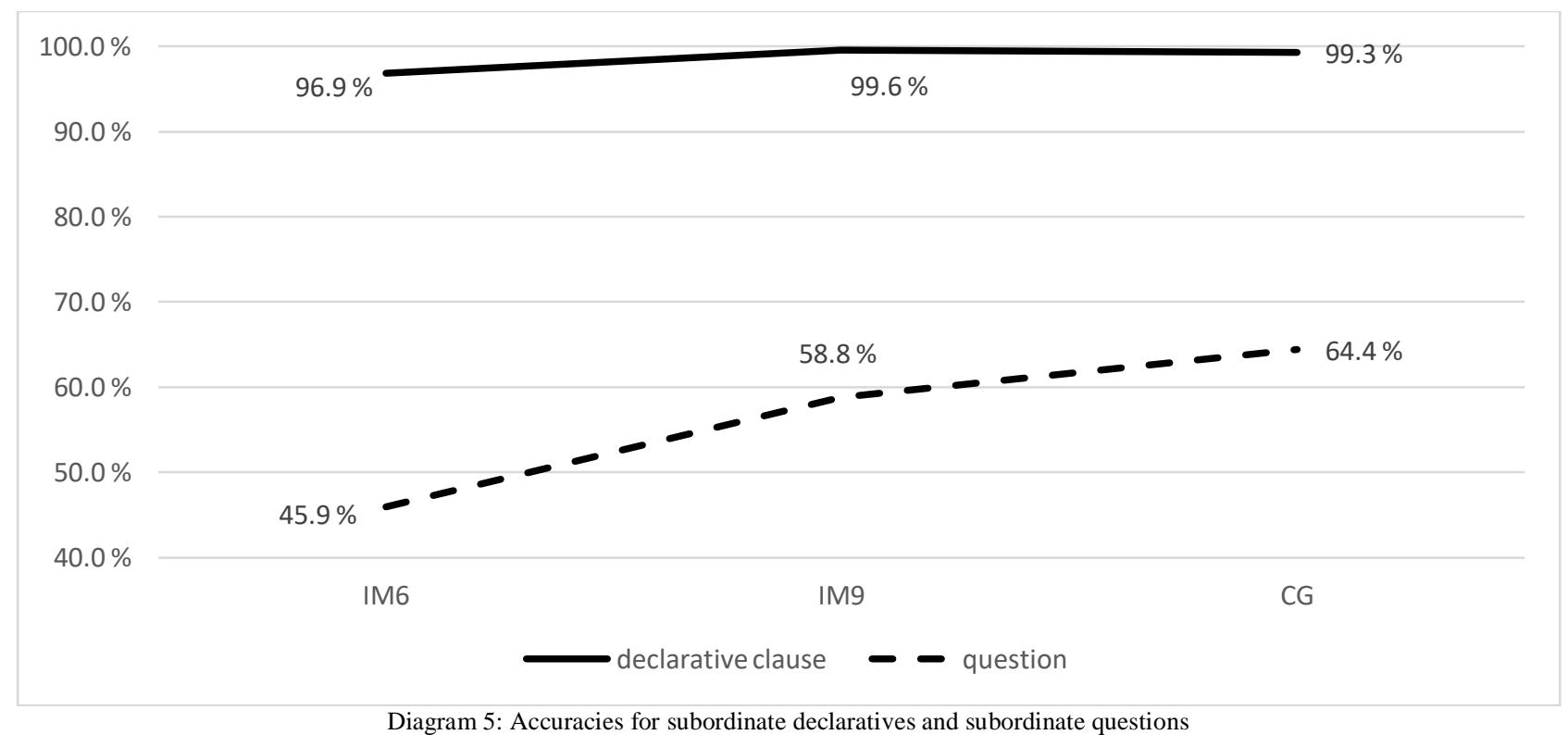

Subordinate clauses diverge from main clauses, as declaratives have significantly higher accuracies than questions $(\mathrm{p}<0.001)$ in all groups, i.e. subordinate questions are more challenging than subordinate declaratives. All differences between the groups are nonsignificant in the subordinate declaratives. The few declarative subordinate clauses with an inaccurate inversion are typically relative clauses beginning with the relative adverb där. This grammatical word has a high functional value (cf. DeKeyser 2005). In subordinate clauses, it is used as a relative adverb of place (meaning "where, in which") with a preceding correlate (Holmes/Hinchcliffe 1994): 


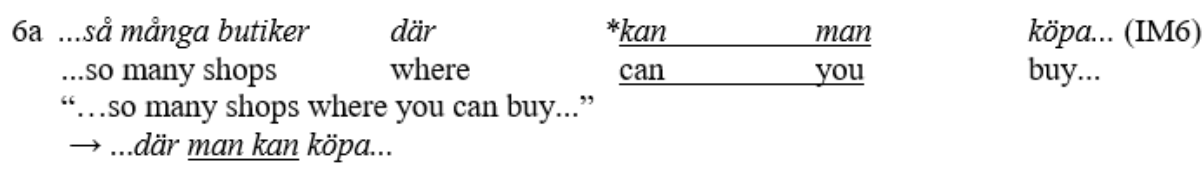

In main clauses, however, där is used as an adverb of place ("there") after which the word order is inverted when där is fronted (Holmes/Hinchcliffe 1994). These two clause types are likely to intermingle for the informants (cf. Rahkonen/Håkansson 2008; Ganuza 2008).

The subordinate questions reach significantly lower accuracies than direct questions ( $p<0.001$ in all groups; cf Ganuza 2008). Also declarative main clauses reach higher accuracies than subordinate declaratives, but the difference is significant only in IM6 $(\mathrm{p}<0.001)$. Accuracies for subordinate questions are significantly higher in IM9 and CG than in IM6 ( $\mathrm{p}=0.038$ and $\mathrm{p}=0.007$, respectively). The typical inaccuracy in subordinate questions is, as in previous research (Hyltenstam/Lindberg 1983; Viberg 1990; Ganuza 2008; Hagen 1992; Nyqvist 2020, 2021) overuse of inversion:

6b. Hon frågade
$\begin{aligned} & \text { She asked } \\ & \text { "She asked if I needed help...." }\end{aligned}$
$\rightarrow[\ldots]$ om jag behövde hjälp...

hjälp att packa. (IM6)

help with packing

\section{"She asked if r needed help...."}

When a direct question is transformed into a subordinate one, the inverted word order of the direct question has to be straightened. This procedure is acquired after the inversion (Håkansson 2004; Rahkonen/Håkansson 2008; see also Nyqvist 2020, 2021 for examples) and might be especially challenging for Finnish-speaking learners, as Finnish subordinate questions have the same word order as direct questions (Hakulinen et al. 2004).$^{8}$ Other factors explaining the low accuracy of subordinate questions are their low frequency in the input (Hultman/Westman 1977; Jörgensen 1978) and the fact that they have a canonical word order although they are questions (cf DeKeyser 2005; an opaque link between form and the meaning). Similar results (Philipsson 2007), especially the fact that immersion students have problems with the word order in subordinate questions in Swedish, have been reached on a grammar test (Nyqvist 2020, 2021), and the actual data confirm that the problems also exist in more spontaneous writing.

\section{DisCUSSION AND CONCLUSION}

This study explores the subject-verb word order in texts written by Finnish-speaking 12- and 15-year-old immersion students and 16-year-old non-immersion students. Word order has been a notorious source of difficulty for L2 learners of Swedish, Danish and Norwegian in previous studies (e.g., Hyltenstam 1988, 1992; Lund 1997; Johannesen 2008), but the actual results reveal that all informant groups have reached high accuracies in both direct questions and declarative main clauses with canonical word order.

When accuracies for direct questions and declaratives with inversion, and those for canonical and inverted word order in declarative main clauses are compared, one sees that declaratives with inversion are significantly more difficult in all three groups. This indicates that inversion is the most challenging subject-verb word order-related learning task in declarative main clauses. This is natural from the usage-based point of view, as the input frequencies for inversion in declarative main clauses are rather low (Jörgensen 1976). The inversion in declaratives also lacks communicative meaning, i.e. it is less salient than in direct questions (Lund 1997). Also, the link between form and meaning is opaque in declarative main clauses with inversion (cf DeKeyser 2005). Moreover, both previously acquired languages of the informants, Finnish and English, lack obligatory inversion (Holmes/Hinchcliffe 1994; Karlsson 2017), which might hamper the acquisition of it (cf Bohnacker 2006). However, inversion in declarative main clauses has a higher accuracy in IM9 than in IM6 and CG, which implies that learning time and rich input received in immersion have a favourable effect on the acquisition. A fronted subordinate clause appears to be one of the challenging contexts in main clauses with inversion, but inaccuracies also occur with fronted adverbials. Hence, it would be beneficial to study the impact of different types of fronted constituents, preferably with data in which these different types have the same number of constituents.

All three groups reach a very high accuracy in subordinate declaratives, i.e. subordinate declaratives do not appear to be challenging. Practically the only problem lies in the use of the relative attribute där ("where"). As this polyfunctional grammatical word is also used as the spatial adverb där ("there") in main clauses where it is commonly fronted, the informants appear to struggle with distinguishing between subordinate and main clauses, which leads to overuse of inversion in subordinate declaratives.

When subordinate declaratives are compared to subordinate questions, the questions have significantly lower accuracies in all groups, i.e. subordinate questions stand out as a very challenging clause type, in which CG reaches significantly higher accuracy than immersion groups (cf. Nyqvist 2020). This also becomes clear when subordinate and

\footnotetext{
${ }^{8}$ E.g., Onko hän sairas? "Is he ill?”; En tiedä, onko hän sairas "I don’t know if he is ill”; Missä hän on? "Where is he?” En tiedä, missä hän on “I don't know where he is". 
direct questions are compared to one another: differences in accuracy are significant in all groups. The challenges provided by subordinate questions can be explained by their low frequency (Jörgensen, 1978, Hultman/Westman 1977), the opaque link between form and meaning (DeKeyser 2005) and by the fact that both direct and indirect questions have similar word orders in Finnish (Hakulinen et al. 2004). In sum, all informant groups, seen as advanced learners of L2 Swedish, produce qualitatively similar inaccuracies for both main and subordinate clauses as the less advanced learners in previous studies (as in Hyltenstam 1988, 1992): they overuse canonical word order in obligatory occasions for inversion in main clauses and inversion in subordinate clauses.

Examining the results using Housen and Simoens' (2016) taxonomy, one can conclude that differences between immersion and non-immersion and between younger and older informants are often significant. CG has received more explicit grammar instruction, but they do not usually reach higher accuracies than IM9, which might depend on the fact that the grammar rules concerning word order often use extensive challenging grammatical terminology (cf. R. Ellis 2006). Comparison of certain constructions such as direct and subordinate questions or declarative and interrogative subordinate clauses, i.e. feature-related factors (such as frequency, salience, and functional value, which are also central to usage-based grammar), by contrast, reveals that they have characteristics explaining why learners struggle with them.

Inaccuracies in word order indeed put comprehensibility in danger, if, e.g., a question is misinterpreted as a declarative due to an inaccurate word order. Another reason to focus on them in L2 instruction is the fact that they label the speaker as an L2 speaker (cf. Nyqvist/Lahtinen 2021). Ảberg (2020), has also found that acquisition of inversion can be enhanced, at least in written production. Hence, it is important to find ways of increasing salience and noticing (Bybee 2008) and, by this means, acquisition of word order (especially inversion in declarative main clauses and canonical word order in subordinate questions) during lessons held in Swedish. As immersion students tend to directly develop implicit knowledge that is available for unconscious use in communication, it is difficult to change afterwards if it includes inaccuracies (R. Ellis 2008). The low frequency of e.g. subordinate clauses can be attended to with skewed input, i.e. input with several occurrences of a problematic construction (Goldberg/Casenhiser 2008). Conscious analyses of input should also be an important part of instruction, as L2 learners tend to neglect the grammar otherwise (DeKeyser 2005; see also Nyqvist 2018ab, 2021; Nyqvist/Lundkvist 2020; Nyqvist/Lahtinen 2021). A deliberate analysis of the language can create aides-memoire that the learners can utilise when analysing other examples of the same construction (Bybee 2008; N. Ellis/Wulff 2015). An increased focus on pattern recognition has also been recommended as an efficient method of L2 instruction by Swedish researchers (Håkansson et al. 2019; Prentice et al. 2016).

Additionally, accurate use of the problematic constructions, such as subordinate questions, should be practised intensely. Practising multiple skills in the same exercise, the so-called interleaving, has been shown to lead to better results in the long run than focusing on one construction at a time, as interleaving is similar to actual language use and permits deeper processing (Nakata/Suzuki 2019). As word order in Swedish comprises different types of constructions, interleaving exercises can be created solely of word order.

Language teachers in immersion settings should not, however, be the only ones enhancing the acquisition of grammar. The counter-balanced approach (Lyster 2007) states that teachers in all subjects should also be able to shift focus from their own subject to linguistic questions when needed. Written input has likewise proved to effectively develop the implicit knowledge (Kim/Godfroid 2019) and noticing of constructions in the written input can then be enhanced, e.g. with different colours or fonts drawing the student's attention to the form. Thus, utterances occurring in any study material can produce formulaic sequences, acting as aides-memoires in the language acquisition. Teachers can also direct the students' attention to the grammar by stressing certain grammatical morphemes in their speech or by their explicit comments that do not need to involve grammatical terminology (e.g. "Did you notice the inverted word order in that clause?"). Immersion has traditionally emphasised rich input and meaningful communication, but when they are conjoined with effective instruction, the learners are likely to reach a high level of competence even in the constructions that challenge them within this study.

\section{REFERENCES}

[1] Allan, R., Holmes, P. \& T. Lundskær-Nielsen. (2000). Danish: An essential grammar. London: Routledge.

[2] Baker, C. (2011). Foundations of bilingual education and bilingualism (5th ed.). Clevedon: Multilingual Matters.

[3] Bergroth, M. (2015). Kotimaisten Kielten Kielikylpy [Immersion in the national languages in Finland]. Publications of the University of Vaasa. Retrieved from http://www.uva.fi/materiaali/pdf/isbn_978-952-476-617-3.pdf_(accessed 18/4/2021)

[4] Bergroth, M. \& S. Björklund. (2013). Kielikylpyohjelman tutkimustuloksia Suomessa [Results from immersion studies in Finland]. In L. Tainio \& H. Harju-Luukkainen (eds.), Kaksikielinen Koulu - tulevaisuuden monikielinen Suomi/Tvåspråkig skola - ett flerspråkigt Finland i framtiden [Bilingual school - a plurilingual Finland of the future]. Studies in Pedagogy 62. Jyväskylä: Finnish Educational Research Association, 91-114.

[5] Bohnacker, U. (2006). When Swedes begin to learn German: From V2 to V2. Second Language Research 22.4, $443-486$. https://doi.org/10.1191/0267658306sr275oa.

[6] Bolander, M. (1988). Nu ja hoppas inte så mycke. Om inversion och placering av negation och adverb i svenska som andraspråk [Now I don't hope that much. On inversion and position of adverbs in L2 Swedish]. In K. Hyltenstam \& I. Lindberg (eds), Första symposiet om svenska som andraspråk. Volym 1. [First Symposium in L2 Swedish. Volume 1]. Stockholm University, Center for Research on Bilingualism, 203-214. 
[7] Brautaset, A. (2004). Er inversjon vanskelig å laere? [Is inversion difficult to acquire?]. In L. Ekberg \& G. Håkansson (eds.), Nordand 6. Sjätte konferensen om Nordens språk som andraspråk [Nordand 6. Sixth conference on Scandinavian languages as L2]. Lund: Lund University, Department of Scandinavian Languages, 1-13.

[8] Bybee, J. (2008). Usage-based grammar and second language acquisition. In P. Robinson \& N.C. Ellis (eds.), Handbook of cognitive linguistics and second language acquisition. New York: Routledge, 216-236.

[9] Collins, L., Trofimovich, P., White, J., Cardoso, W. \& M. Horst. (2009). Some input on the easy/difficult grammar question: An empirical study. Modern Language Journal, 93.3, 336-353. https://doi.org/10.1111/j.1540-4781.2009.00894.x.

[10] DeAngelis, G. (2007). Third or additional language acquisition. Clevedon: Multilingual Matters.

[11] DeKeyser, R. (2003). Implicit and explicit learning. In C.J. Doughty \& M. Long (eds.), The handbook of second language acquisition. Oxford: Blackwell Publishing, 313-348.

[12] DeKeyser, R. (2005). What makes learning second language grammar difficult? A review of issues. Language Learning, 55.S1, 1-25. doi:10.1111/j.0023-8333.2005.00294.x.

[13] Ellis, N.C. (2016). Salience, cognition, language complexity, and complex adaptive systems. Studies in Second Language Acquisition 38.2, 341-351. https://doi.org/10.1017/S027226311600005X.

[14] Ellis, N.C. \& S. Wulff (2015). Usage-based approaches to SLA. In B. VanPatten \& J. Williams (eds.), Theories in second language acquisition: An introduction. New York: Routledge, 75-93.

[15] Ellis, R. (2006). Modelling learner difficulty and second language proficiency: The differential contributions of implicit and explicit knowledge. Applied Linguistics 27.3, 431-463. doi:10.1093/applin/aml022.

[16] Ellis, R. (2008). The study of second language acquisition (2nd ed.). Oxford: Oxford University Press.

[17] Ellis, R. \& G. Barkhuizen. (2005). Analysing learner language. Oxford: Oxford University Press.

[18] FNBE 2014a = Finnish National Board of Education (2014). Koulutuksen tilastollinen vuosikirja 2014 [Statistical annals of education 2014]. Helsinki: Finnish National Board of Education. Retrieved from http://www.oph.fi/download/163331_koulutuksen_tilastollinen_vuosikirja_2014.pdf. (accessed 18/4/2021).

[19] FNBE 2014b = Finnish National Board of Education. (2014). Perusopetuksen opetussuunnitelman perusteet [Core curriculum for basic education]. Helsinki: Finnish National Board of Education. Retrieved from http://www.oph.fi/download/139848_pops_web.pdf. (accessed 18/4/2021).

[20] FNBE 2015 = Finnish National Board of Education. (2015). Lukion opetussuunnitelman perusteet [Core curriculum for general upper secondary schools]. Helsinki: Finnish National Board of Education. Retrieved from http://www.oph.fi/download/172124_lukion_opetussuunnitelman_perusteet_2015.pdf. (accessed 18/4/2021).

[21] Ganuza, N. (2008). Syntactic variation in the Swedish of adolescents in multilingual urban settings. Subject-verb word order in declaratives, questions and subordinate clauses. Stockholm: Centre for Research on Bilingualism, Stockholm University.

[22] Genesee, F. (2004). What do we know about bilingual education for majority language students? In T.K. Bhatia \& W.C. Ritchie (eds.), Handbook of bilingualism. Malden, MA: Blackwell, 547-576.

[23] Goldberg A \& D. Casenhiser. (2008). Construction learning and second language acquisition. In P. Robinson \& N.C. Ellis (eds.), Handbook of cognitive linguistics and second language acquisition. New York: Routledge, 197-215.

[24] Goldschneider, J. \& R. DeKeyser. (2001). Explaining the "natural" order of L2 morpheme acquisition in English: A metaanalysis of multiple determinants. Language Learning 51.1, 1-50. https://doi.org/10.1111/1467-9922.00147.

[25] Government Decree 422/2012. Retrieved

from http://www.oph.fi/download/179422_distribution_of_lesson_hours_in_basic_education_2012.pdf. (accessed 18/4/2021)

[26] Hagen, J.E. (1992). Feilinvertering, overinvertering og underinvertering. Norsk som andrespråk 15, 27-36.

[27] Hakulinen, A., Vilkuna, M., Korhonen, R., Koivisto, V., Heinonen, T-R. \& I. Alho. (2004). Iso suomen kielioppi [Big Finnish grammar]. Helsinki: The Finnish Literature Society.

[28] Hammarberg, B. (2008). Konstruktioner som produkt och process - en studie av hur L1- och L2-talare utnyttjar "det är". Nordisk tidsskrift for andraspråksforskning 3 79-107.

[29] Harley, B. (1993). Instructional strategies and SLA in early French immersion. Studies in Second Language Acquisition, 15.2, 245-260. doi:10.1017/S0272263100011980.

[30] Harley, B. (1998). The role of focus-on-form tasks in promoting child L2 acquisition. In C. Doughty \& J. Williams (eds), Focus on form in classroom second language acquisition. Cambridge: Cambridge University Press, 156-174.

[31] Holmes, P. \& I. Hinchcliffe. (1994). Swedish: A comprehensive grammar (2nd ed.). New York: Routledge.

[32] Housen, A. \& H. Simoens. (2016). Introduction: Cognitive perspectives on difficulty and complexity in L2 acquisition. Studies in Second Language Acquisition, 38.2, 163-175. doi: 10.1017/S0272263116000176.

[33] Hultman, T.G. \& M. Westman. (1977). Gymnasistsvenska [Swedish in upper secondary school]. Lund: Liber Läromedel.

[34] Hyltenstam, K. (1978). Variability in interlanguage syntax. Working papers 18. Lund: Lund University.

[35] Hyltenstam, K. (1988). Att tala svenska som en infödd - eller nästan [To speak Swedish as a native speaker - almost]. In K. Hyltenstam \& I. Lindberg (eds.), Första symposiet om svenska som andraspråk. Volym 1. [First Symposium in L2 Swedish. Volume 1]. Stockholm University, Center for Research on Bilingualism, 138-156.

[36] Hyltenstam, K. (1992). Non-native features of near-native speakers. On the ultimate attainment of childhood L2 learners. In R. Harris (ed), Cognitive processing in bilinguals. Amsterdam: Elsevier Science Publishers, 351-368.

[37] Hyltenstam, K. \& I. Lindberg. (1983). Invandrares svenska. En kritisk genomgång av materialet i projektet svenska för invandrare (Josefson 1979), särskilt med avseende på dess vidare användningsmöjligheter. In B. Hammarberg (ed.), Studium av ett invandrarsvenskt språkmaterial [A study of linguistic data from immigrants in Sweden]. SSM Report 9, Stockholm University, 5-71.

[38] Håkansson, G. (1987). Teacher talk. How teachers modify their speech when addressing learners of Swedish as a second language. Lund: Lund University Press.

[39] Håkansson, G. (1988). "Hungry I am - breakfast I want". On the acquisition of inverted word order in Swedish. Working papers 33. Lund: Lund University, 123-130. 
[40] Håkansson, G. (1998). Modern times in L2 Swedish. Syntax and morphology in formal and informal acquisition of Swedish. In I. Diaz \& C. Perez (eds.), Views on the acquisition and use of a second language. EUROSLA 7 Proceedings. Barcelona: Universitat Pompeu Fabra, 39-50.

[41] Håkansson, G. (2004). Utveckling och variation i svenska som andraspråk enligt processbarhetsteorin [Development and variation in L2-Swedish according to the Processability Theory]. In K. Hyltenstam \& I. Lindberg (eds.), Svenska som andraspråk - i forskning, undervisning och samhälle [Swedish as an L2 - in research, instruction and society]. Lund: Studentlitteratur, 153-169.

[42] Håkansson C., Lyngfelt, B., \& M. Brasch. (2019). Typfall och mönsterigenkänning - konstruktionsbaserad andraspråksundervisning i praktiken [Typical cases and pattern recognition - constructions-based L2 instruction in practise]. In M. Bianchi, D. Håkansson, B. Melander \& L. Pfister (eds.), Svenskans beskrivning 36 [Describing Swedish 36]. Uppsala: Uppsala University, 107-117.

[43] Jaakkola, H. (2000). Kielitiedosta kielitaitoon [From the knowledge about languages to the language proficiency]. In P. Kaikkonen \& V. Kohonen (eds.), Minne menet kielikasvatus? Näkökulmia kielipedagogiikkaan [Where are you going, language education? Viewpoints into language pedagogy]. Jyväskylä: University of Jyväskylä, 145-156.

[44] Jensen, I., Slabakova, R., Westergaard, M. \& B. Lundquist. (2020). The Bottleneck Hypothesis in L2 acquisition: L1 Norwegian learners' knowledge of syntax and morphology in English. Second Language Research 36.1, 3-29. https://doi.org/10.1177/0267658318825067.

[45] Johansen, H. (2008). Inversjon i norsk innlærerspråk. En undersøkelse av variasjonsmønstre i skrevne tekster [Inversion in L2 Norwegian. A study on variation patterns in written texts]. NOA norsk som andrespråk 2, 50-71.

[46] Jörgensen, N. (1976). Meningsbyggnaden i talad svenska [Sentence structure in spoken Swedish]. Lund: Studentlitteratur.

[47] Jörgensen, N. (1978). Underordnade satser och fraser i talad svenska: Funktion och byggnad [Subordinate clauses and phrases in spoken Swedish]. Lund: Walter Ekstrands.

[48] Karlsson F (2017). Finnish: A comprehensive grammar. New York: Routledge.

[49] Kim, K.M. \& A. Godfroid. (2019). Should we listen or read? Modality effects in implicit and explicit knowledge. The Modern Language Journal 93.3, 648-664. https://doi.org/10.1111/modl.12583.

[50] Lange, S. \& K. Larsson. (1973). Syntactic development of a Swedish girl Embla between 20 and 24 months of age. Part 1. Report no 1. Stockholm. Institution for nordiska språk.

[51] Lieven, E. \& M Tomasello. (2008). Children's first language acquisition. In P. Robinson \& N.C. Ellis (eds.), Handbook of cognitive linguistics and second language acquisition. New York: Routledge, 168-196.

[52] Lund, K. (1997). Lærer alle på samme måde? En længdeundersøgelse af voksnes tilegnelse af dansk som andetsprog [Do all learners acquire Danish in the same developmental sequences? A longitudinal research project of Danish Second language acquisition by adults]. Copenhagen: Special-pædagogisk Forlag.

[53] Lyster, R. (2007). Learning and teaching languages through content: A counterbalanced approach. Amsterdam/Philadelphia: John Benjamins.

[54] Nakata, T. \& Y. Suzuki (2019). Mixing grammar exercises facilitates long-term retention: Effects of blocking, interleaving, and increasing practice. The Modern Language Journal, 103.3, 629-647. doi: https://doi.org/10.1111/modl.12581.

[55] Nyqvist, E-L. (2018a). Definiteness and Use of Articles in Written Swedish by Finnish-speaking Immersion Pupils at the End of Immersion: A Comparison with Non-immersion Students. Journal of Immersion and Content-based Language Education $6.1,57-84$.

[56] Nyqvist, E-L. (2018b). Species och artikelbruk hos finska språkbadselever i årskurs 6. Folkmålsstudier 56, 73-104. https://journal.fi/folkmalsstudier/article/view/89161.

[57] Nyqvist, E-L. (2020). Interrogativa bisatser hos 12- och 15-åriga språkbadselever. En jämförelse med traditionell undervisning. [Interrogative subordinate clauses in Swedish by 12-and 15-years-old Finnish-speaking immersion students. A comparison with non-immersion students] In C. Wide, E. Ingman, K. Lankinen \& V. Vaakanainen (eds.) Svenskan i Finland 18 [Swedish in Finland 18]. Turku: University of Turku, 164-180. https://www.utupub.fi/handle/10024/150838

[58] Nyqvist, E-L. \& Lundkvist, P. (2020). De lokala prepositionerna hos finska svenskinlärare i språkbad och traditionell undervisning [Local prepositions by Finnish-speaking immersion and non-immersion pupils]. In S. Haapamäki, L. Forsman \& L. Huldén (eds.) Svenskans beskrivning 37 [Describing Swedish 37]. Turku: Åbo Akademi University, $215-229$. https://www.doria.fi/handle/10024/180219.

[59] Nyqvist, E-L. (2021). Interrogative Subordinate Clauses in Swedish by 12-and 15-Years-Old Finnish-speaking Immersion Students. Folia Scandinavica Posnaniensia 30, 15-25. DOI: 10.2478/fsp-2021-0002.

[60] Nyqvist, E-L. \& Lahtinen, S. (2021). Grammatical gender in L2 Swedish by Finnish-speaking immersion students. A comparison with non-immersion students. Nordic Journal of Linguistics 44.2, 1-23. DOI: https://doi.org/10.1017/S0332586520000256.

[61] Ó Duibhir, P. (2009). The spoken Irish of sixth-class pupils in Irish immersion schools. Dublin: University of Dublin, Trinity College, Centre for Language and Communication studies.

[62] Philipsson, A. (2007). Interrogative clauses and verb morphology in L2 Swedish. Theoretical interpretations of grammatical development and effects of different elicitation techniques. Stockholm: Stockholm University.

[63] Pienemann, M. \& G. Håkansson. (1999). A unified approach towards the development of Swedish as L2. A processability account. Studies in Second Language Acquisition 21.3, 383-420. https://doi.org/10.1017/S0272263199003022.

[64] Prentice, J., Loenheim, L., Lyngfelt, B., Olofsson, J. \& S. Tingsell. (2016). Bortom ordklasser och satsdelar: Konstruktionsgrammatik i klassrummet. [Beyond word classes and sentence constituents: Construction grammar in the classroom]. In A.W. Gustafsson, L. Holm, K. Lundin, H. Rahm \& M. Tronnier (eds.), Svenskans beskrivning 34 [Describing Swedish 34]. Lund: Lund University, 385-397.

[65] Rahkonen, M. \& G. Håkansson. (2008). Production of written L2-Swedish - Processability or input frequencies? In J-U. Kessler (ed.), Processability approaches to second language development and second language learning. Cambridge Scholars Publishing, 135-161. 
[66] Saarik, K. (2006). Tilegnelsen av V2-regelen hos estisk og finsktalende innlærere av norsk som andrespråk [Acquisition of the V2 rule by Estonian and Finnish L2-learners of Norwegian]. In H. Sandoy, \& K. Tenfjord (eds.), Den nye norsken [The new Norwegian]. Oslo: Novus Forlag, 246-259.

[67] Salameh, E-K., Håkansson, G. \& U. Nettelbladt. (1996). The acquisition of Swedish as a second language in a group of Arabicspeaking pre-school children: Word order and phrasal morphology. Logopedics, Phoniatrics, Vocology 21.3-4, 163-170. doi:10.3109/14015439609098885.

[68] Strandskogen, Å-B. \& R. Strandskogen. (1995). Norwegian: An essential grammar. London: Routledge.

[69] Teleman, U., Hellberg, S. \& E. Andersson. (1999a). Svenska Akademiens Grammatik. [Grammar of the Swedish Academy] Vol. 2. Stockholm: Svenska Akademien.

[70] Teleman, U., Hellberg, S. \& E. Andersson. (1999b). Svenska Akademiens Grammatik. [Grammar of the Swedish Academy] Vol. 4. Stockholm: Svenska Akademien.

[71] Viberg, A. (1990). Bisatser i inlärarsperspektiv [Subordinate clauses from a L2 perspective]. In G. Tingbjörn (ed), Andra Symposiet om svenska som andraspråk i Göteborg 1989 [Second Symposium on Swedish as an L2 in Gothemburg 1989]. Stockholm: Scriptor, 388-362.

[72] Wray, A. (2012). Formulaic language: Pushing the boundaries. Oxford: Oxford University Press.

[73] Åberg, A-M. (2020). Effekten av explicit undervisning på inlärning av explicit och implicit kunskap om ordföljden i svenska. [The effect of explicit instruction on the acquisition of implicit and explicit knowledge of the word order in Swedish]. Turku: University of Turku.

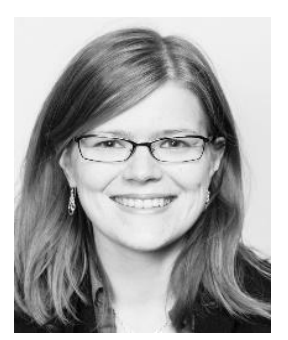

Eeva-Liisa Nyqvist was born in Turku, Finland. She got her master's degree in Scandinavian languages in 2004 and her doctoral degree in Scandinavian languages in 2013, both from the university of Turku. She works as a postdoctoral researcher in Swedish as a second language at the department of Finnish, FinnoUgrian and Scandinavian studies, Faculty of Humanities, University of Helsinki, Finland.

She has previously worked as University Teacher and University Lecturer in Scandinavian languages at the University of Eastern Finland and at the University of Helsinki, and as a Collegium Postdoctoral Researcher at Turku Institute of Advanced Studies at the University of Turku. Her research interests include second language grammar, immersion, multilingualism, intercomprehension of closely related languages and translation theory. 